\title{
Evaluasi Kuantitatif Penggunaan Antibiotik di Ruang Perawatan Airlangga dan Peta Kuman RSUD Kanjuruhan Malang Periode Juli-Desember 2018
}

\author{
Wirda Anggraini, Hajar Sugihantoro, Firda Ludfiyah \\ Jurusan Farmasi, Fakultas Kedokteran dan Ilmu Kesehatan, \\ Universitas Islam Negeri Maulana Malik Ibrahim Malang, Malang, Indonesia
}

\begin{abstract}
Abstrak
Antibiotik merupakan salah satu obat yang paling banyak dikonsumsi secara luas di tempat layanan kesehatan. Tingginya jumlah penggunaan antibiotik yang tidak tepat dapat mengakibatkan terjadinya resistensi, efek samping dan biaya rumah sakit yang meningkat. Salah satu upaya untuk mengendalikan resistensi antibiotik di rumah sakit adalah pelaksanaan evaluasi penggunaan antiobiotik. Penelitian ini bertujuan untuk mengetahui profil penggunaan antibiotik dan peta kuman, serta melakukan evaluasi kuantitatif. Penelitian ini merupakan penelitian observasional deskriptif menggunakan desain cross-sectional melalui data rekam medik pasien Ruang Perawatan Airlangga bulan Juli-Desember 2018 dan data peta kuman tahun 2018 RSUD Kanjuruhan Malang yang diambil secara retrospektif. Didapatkan 75 sampel rekam medis yang kemudian dianalisis secara kuantitatif menggunakan metode ATC/ DDD. Hasil penelitian ini menunjukkan bahwa golongan antibiotik terbanyak yang digunakan adalah golongan Cephalosporin (86\%) dengan tiga antibiotik tertinggi adalah Cefoperazone (43,90\%), Ceftriaxone (18,29\%), dan Cefotaxime (13,41\%). Dari hasil analisis kuantitatif penggunaan antibiotik dengan metode ATC/DDD, didapatkan nilai total DDD/100 patient days sebesar 66,44 dengan antibiotik tertinggi adalah Cefoperazone (20,72), dan Ceftriaxone (20,18). Antibiotik yang masuk dalam segmen 90\% antara lain Cefoperazone (parenteral) 31,19\%, Ceftriaxone (parenteral) 30,37\%, Cefotaxime (parenteral) 12,45\%, Levofloxacin (parenteral) 5,19\%, Levofloxacin (oral) 4,88\%, dan Metronidazole (parenteral) 4,73\%. Isolat bakteri yang diperoleh dari laboratorium mikrobiologi berjumlah 120 isolat dengan distribusi bakteri gram positif $(49,17 \%)$ dan bakteri gram negatif $(50,83 \%)$. Isolat bakteri gram positif terbanyak adalah Staphylococcus aureus $(30 \%)$ dan bakteri gram negatif terbanyak adalah Escherichia coli (15\%) dengan sensitivitas antibiotik terbaik untuk bakteri gram positif adalah Clarithomicyn $(81,8 \%)$ dan untuk bakteri gram negatif adalah Amikacin $(77,8 \%)$.
\end{abstract}

Kata kunci: Antibiotik, DDD/100 patient days, DU 90\%, peta kuman

\section{A Quantitative Evaluation of the Antibiotic Use in Airlangga Ward and Microorganism Pattern in Kanjuruhan Regional General Hospital Malang, between July and December 2018}

\begin{abstract}
Antibiotics are the most widely used class of drugs in health care, however, the abuse of these drugs leads to resistance, side effects, and increased hospital costs. The evaluation of antibiotics use is a possible attempt to control antibiotic resistance in hospitals. Therefore, this study aimed to determine the profile of antibiotic use, microorganism pattern, and perform a quantitative evaluation. Using an observational descriptive method study with a cross-sectional design, data were retrospectively retrieved from medical records of patients admitted in Airlangga Ward between July and December 2018, as well as the microorganism pattern in Kanjuruhan Region General Hospital Malang 2018. A total of 75 medical record samples were obtained and these were further analyzed using the ATC/DDD method. According to the results, the most used antibiotics group was Cephalosporin (86\%), particularly Cefoperazone (43.90\%), Ceftriaxone (18.29\%), and Cefotaxime (13.41\%). In addition, the quantitative analysis of antibiotics use showed the total DDD/100 patient days was 66.44 with Cefoperazone (20.72) and Ceftriaxone (20.18). The antibiotics included in the 90\% segment were Cefoperazone (parenteral) $31.19 \%$, Ceftriaxone (parenteral) 30.37\%, Cefotaxime (parenteral) 12.45\%, Levofloxacin (parenteral) 5.19\%, Levofloxacin (oral) 4.88\%, and Metronidazole (parenteral) 4.73\%. Meanwhile, a total of 120 bacterial isolates (49.17\% gram-positive and 50.83\% gram-negative) were obtained from the microbiology laboratory, with the most prevalent gram-positive and negative isolates being Staphylococcus aureus (30\%) and Escherichia coli $(15 \%)$, respectively. Also, the best antibiotic sensitivity for gram-positive and negative bacteria was recorded for Clarithomicyn (81.8\%) and Amikacin (77.8\%), respectively.
\end{abstract}

Keywords: Antibiotics, DDD/100 patient days, DU 90\%, microorganism pattern

Korespondensi: apt. Wirda Anggraini, M.Farm, Jurusan Farmasi, Fakultas Kedokteran dan Ilmu Kesehatan, Universitas Islam Negeri Maulana Malik Ibrahim Malang, Malang, Jawa Timur 65144, Indonesia, email: wirdaanggraini93@gmail.com Naskah diterima: 12 Mei 2020, Diterima untuk diterbitkan: 15 Februari 2021, Diterbitkan: 30 Juni 2021 


\section{Pendahuluan}

Infeksi merupakan penyakit yang disebabkan oleh adanya bakteri di dalam tubuh yang menyebabkan kerusakan jaringan tubuh. Setiap tahun di negara-negara berpenghasilan rendah dan menengah, sebagian besar kematian pada 3,5 juta orang yang terdiri dari anak-anak miskin diakibatkan oleh penyakit infeksi. ${ }^{1}$ Penyakit infeksi merupakan salah satu masalah kesehatan yang paling utama di negara-negara berkembang termasuk Indonesia.

Antibiotik merupakan salah satu obat yang paling banyak dikonsumsi secara luas di dunia. Sebanyak 13-37\% pasien yang dirawat di rumah sakit di negara maju mendapatkan pengobatan antibiotik dalam bentuk tunggal maupun kombinasi, sedangkan di negara berkembang sebanyak 30-80\%. Data Centers for Disease Control and Prevention (CDC) menyatakan bahwa hingga 50\% peresepan antibiotik digunakan untuk pasien yang tidak membutuhkan dan tidak mendapatkan efek secara optimal. ${ }^{2}$

Salah satu permasalahan yang diakibatkan oleh tingginya penggunaan antibiotik adalah resistensi. Resistensi terjadi saat bakteri berubah dan menyebabkan menurunnya atau hilangnya efektivitas obat dalam mencegah maupun mengobati infeksi. ${ }^{3}$ Beberapa upaya untuk mengendalikan resistensi antibiotik di rumah sakit dapat berupa penggunaan antibiotik secara bijak dan melakukan evaluasi penggunaan antiobiotik. Satuan penggunaan obat yang direkomendasikan oleh World Health Organization (WHO) sejak tahun 1996 dalam evaluasi penggunaan obat (EPO) adalah sistem Anatomy Therapeutic Chemical (ATC)/Defined Daily Dose (DDD). Metode yang dapat digunakan untuk mengidentifikasi permasalahan yang timbul terkait kebijakan penggunaan antibiotik selain DDD/100 patient days adalah Drug Utilization (DU) $90 \%$. Prinsipnya dengan analisis penggunaaan antibiotik melalui perhitungan segmen $90 \%$, yaitu dengan mempersentasikan penggunaan obat antibiotik dari terbesar hingga terkecil. Metode ini diperlukan untuk menekankan obat yang masuk dalam segmen $90 \%$ terkait evaluasi, pengendalian penggunaan, serta perencanaan pengadaan obat. Selain itu, metode ini dapat digunakan untuk meminimalkan efek negatif penggunaan antibiotik. ${ }^{4,5}$

Penelitian serupa sebelumnya dilakukan di Bangsal Penyakit Dalam RSUD Bangil pada periode Juli-Desember 2016 menggunakan perhitungan DDD dengan metode Bed Occupancy Rate (BOR). Dalam penelitian ini, perhitungan DDD dilakukan dengan menggunakan metode Length of Stay (LOS) dengan mengetahui profil peta kuman untuk memperoleh hubungan kuantitatif antara penggunaan antibiotik dengan perubahan pola resistensi bakteri patogen terhadap antibiotik. ${ }^{6}$ Berdasarkan hal tersebut, evaluasi penggunaan antibiotik secara kuantitatif penting dilakukan guna mengetahui penggunaan antibiotik dan pencegahan resisten di rumah sakit. Tujuan penelitian ini adalah untuk mengetahui profil penggunaan antibiotik dan peta kuman, serta melakukan evaluasi kuantitatif penggunaan antibiotik.

\section{Metode}

Penelitian ini menggunakan rancangan penelitian observasional dengan pendekatan retrospektif deskriptif secara cross-sectional. Pengambilan data rekam medik pasien dan peta kuman yang memenuhi kriteria inklusi dan eksklusi di ruang rekam medik dan ruang RSUD Kabupaten Kanjuruhan dilakukan secara retrospektif pada bulan Juli-September 2019. Penelitian telah dinyatakan laik etik oleh Komite Etik Penelitian Kesehatan RSUD Kanjuruhan dengan nomor 72.1/EA.KEPK020/35.07.208/2019.

Populasi dalam penelitian ini adalah seluruh data rekam medik pasien Ruang Perawatan Airlangga periode Juli-Desember 2018 dan 
peta kuman RSUD Kanjuruhan Kabupaten Malang tahun 2018. Sampel dalam penelitian ini adalah rekam medik yang memenuhi kriteria inklusi dan kriteria eksklusi, yakni sebanyak 75 rekam medik. Kriteria inklusi antara lain: pasien dewasa Ruang Perawatan Airlangga yang menggunakan antibiotik dengan rentang usia 18-65 tahun; pasien dengan rekam medik yang lengkap meliputi nomor rekam medik pasien, inisial/nama pasien, usia, jenis kelamin, tanggal masuk dan keluar rumah sakit, diagnosis dokter, serta data penggunaan antibiotik lengkap meliputi: nama antibiotik, dosis antibiotik (gram), dan lama penggunaan antibiotik. Kriteria eksklusi adalah pasien dengan terapi antibiotik jangka pendek dihentikan (terapi antibiotik belum selesai) karena pasien pulang paksa, dirujuk atau pasien meninggal.

Evaluasi kuantitatif dilakukan dengan cara analisis deksriptif untuk memperoleh gambaran hasil penelitian. Data perhitungan DDD yang diperoleh kemudian dianalisis menggunakan Microsoft Excel 200. DDD diasumsikan sebagai dosis pemeliharaan rata- rata per hari yang diperkirakan untuk indikasi utama orang dewasa, sebagai berikut: ${ }^{7}$

$\mathrm{DDD} / 100$ patient days

$$
=\frac{\text { Jumlah gram* }^{*}}{\text { Standar DDD WHO dalam gram }} \times \frac{100}{\text { Total LoS }}
$$

Keterangan:

*=Jumlah gram antibiotik yang digunakan oleh pasien.

\section{Hasil}

Berdasarkan Tabel 1 mengenai karakteristik pasien, diketahui bahwa jenis kelamin pasien perempuan lebih banyak dibandingkan lakilaki yaitu sebesar 63\% dengan rentang usia terendah pada usia $17-25$ tahun (5\%) dan 26-35 tahun (4\%), sedangkan rentang usia tertinggi adalah 56-65 tahun (50\%), yaitu sebanyak 37 pasien. Berdasarkan penggunaan antibiotik, diketahui bahwa dari 14 macam antibiotik yang digunakan, Cephalosporin merupakan golongan antibiotik yang paling banyak digunakan $(86 \%)$. Cara pemberian antibiotik terbanyak adalah dengan pemberian antibiotik secara tunggal (97\%).

Tabel 1 Demografi Pasien dan Profil Penggunaan Antibiotik Ruang Perawatan Airlangga RSUD Kanjuruhan Periode Juli-Desember 2018

\begin{tabular}{lcc}
\hline \multicolumn{1}{c}{ Karakteristik Pasien } & Jumlah $(\mathbf{N}=\mathbf{7 5})$ & Persentase (\%) \\
\hline Jenis Kelamin & & \\
Wanita & 28 & 37,3 \\
Pria & 47 & 62,7 \\
Usia (tahun) & & \\
$17-25$ & 4 & 5,3 \\
$26-35$ & 3 & 4,0 \\
$36-45$ & 9 & 12,0 \\
$46-55$ & 22 & 29,3 \\
$56-65$ & 37 & 49,4 \\
Cara Pemberian & & \\
Tunggal & 73 & 97 \\
Kombinasi & 2 & 3 \\
Golongan Antibiotik & & \\
Penicillin & 1 & 1 \\
Imidazole & 1 & 1 \\
Macrolide & 1 & 1 \\
Floroquinolone & 8 & 12 \\
Cephalosporin & 64 & 86 \\
\hline
\end{tabular}


Hasil perhitungan nilai DDD/100 patientdays yang terdapat pada Tabel 2 menunjukkan bahwa jumlah penggunaan DDD/100 patient days tertinggi adalah Cefoperazone $(20,72)$, dan Ceftriaxone $(20,18)$. Total DDD/100 patient days sebesar 66,44 DDD/100 patient days. Hal ini berarti dalam 100 hari, ratarata setiap pasien mendapatkan 66,44 DDD antibiotik tiap harinya. Golongan antibiotik yang memiliki nilai DDD terbesar adalah golongan Cephalosporin generasi ketiga dengan nilai total DDD 50,53 DDD/100 patient days. Selain itu, golongan antibiotik yang memiliki nilai DDD melebihi standar WHO yaitu golongan Cephalosporin generasi ketiga, Floroquinolone dan Imidazole. Nilai DDD yang melebihi standar menunjukkan penggunaan antibiotik yang tinggi dan merupakan salah satu penyebab terjadinya resistensi. Data Tabel 3 menunjukkan bahwa antibiotik yang masuk dalam segmen $90 \%$ terdiri dari Cefoperazone (parenteral) 31,19\%,
Ceftriaxone (parenteral) 30,37\%, Cefotaxime (parenteral) 12,45\%, Levofloxacin (parenteral) $5,19 \%$, Levofloxacin (oral) 4,88\%, dan Metronidazole (parenteral) 4,73\%.

Penggunaan antibiotik yang terlalu banyak/ tidak bijak berdampak pada perburukan profil peta kuman, dan sebaliknya, pengurangan penggunaan antibiotik serta penggunaan yang bijak akan memperbaiki profil peta medan kuman, sehingga peta kuman di rumah sakit dapat digunakan sebagai salah satu bentuk pengawasan penggunaan antibiotik. ${ }^{8,9}$ Analisis didasarkan pada korelasi/hubungan yang paling kuat dengan perubahan pola resistensi bakteri patogen terhadap antibiotik. ${ }^{6}$

Berdasarkan Gambar 1 pada hasil pola kuman pada spesimen pus dengan jenis bakteri gram positif tahun 2018, dapat diketahui bahwa antibiotik dengan presentase effective clinically tertinggi yaitu Doxycyclin (100\%), sedangkan antibiotik dengan presentase not effective clinically tertinggi yaitu Amoxicillin

Tabel 2 Perhitungan Nilai DDD/100 Patient Days

\begin{tabular}{|c|c|c|c|c|c|c|c|c|c|c|c|c|c|}
\hline \multirow{2}{*}{ No. } & \multirow{2}{*}{$\begin{array}{l}\text { Kode } \\
\text { ATC }\end{array}$} & \multirow{2}{*}{$\begin{array}{c}\text { Nama } \\
\text { Antibiotik }\end{array}$} & \multirow{2}{*}{ Golongan } & \multirow{2}{*}{$\begin{array}{c}\text { Standar } \\
\text { WHO } \\
\text { (gram) }\end{array}$} & \multirow{2}{*}{ Rute } & \multirow{2}{*}{ LOS } & \multicolumn{7}{|c|}{ DDD/100 Patient Days } \\
\hline & & & & & & & Juli & Agst & Sept & Okt & Nov & Des & Total \\
\hline 1 & J01CA04 & Amoxicillin & Penicillin & 1,5 & $\mathrm{O}$ & 478 & 0,00 & 0,00 & 0,00 & 0,00 & 0,21 & 0,00 & 0,21 \\
\hline 2 & J01DB05 & Cefadroxil & $\begin{array}{c}\text { Cephalosporin } \\
\text { I }\end{array}$ & 2 & $\mathrm{O}$ & & 0,00 & 0,10 & 0,00 & 0,00 & 0,00 & 0,00 & 0,10 \\
\hline 3 & $\mathrm{~J} 01 \mathrm{DC} 02$ & Cefuroxime & $\begin{array}{c}\text { Cephalosporin } \\
\text { II }\end{array}$ & 3 & $P$ & & 0,00 & 0,00 & 0,00 & 0,00 & 0,84 & 1,99 & 2,83 \\
\hline 4 & J01DD01 & Cefotaxime & $\begin{array}{c}\text { Cephalosporin } \\
\text { III }\end{array}$ & 4 & $P$ & & 0,47 & 1,41 & 0,63 & 0,00 & 0,63 & 5,13 & 8,27 \\
\hline 5 & J01DD02 & Ceftazidime & $\begin{array}{c}\text { Cephalosporin } \\
\text { III }\end{array}$ & 4 & $P$ & & 0,94 & 0,00 & 0,00 & 0,00 & 0,42 & 0,00 & 1,36 \\
\hline 6 & J01DD04 & Ceftriaxone & $\begin{array}{c}\text { Cephalosporin } \\
\text { III }\end{array}$ & 2 & $P$ & & 2,09 & 1,88 & 5,44 & 4,18 & 4,39 & 2,20 & 20,18 \\
\hline 7 & J01DD12 & Cefoperazone & $\begin{array}{c}\text { Cephalosporin } \\
\text { III }\end{array}$ & 4 & $\mathrm{P}$ & & 3,56 & 2,30 & 3,77 & 7,32 & 0,84 & 2,93 & 20,72 \\
\hline 8 & J01DH02 & Meropenem & Carbepenem & 3 & $\mathrm{P}$ & & 0,00 & 0,84 & 0,00 & 0,00 & 0,00 & 0,00 & 0,84 \\
\hline 9 & J01FA10 & Azithromycin & Macrolide & 0,3 & $\mathrm{O}$ & & 0,00 & 0,00 & 1,05 & 0,00 & 0,00 & 0,00 & 1,05 \\
\hline 10 & J01MA02 & Ciprofloxacin & Floroquinolone & 0,8 & $\mathrm{P}$ & & 0,00 & 0,42 & 0,00 & 0,00 & 0,21 & 0,21 & 0,84 \\
\hline 11 & J01MA02 & Ciprofloxacin & Floroquinolone & 1 & $\mathrm{O}$ & & 0,00 & 0,00 & 0,00 & 0,00 & 0,00 & 0,21 & 0,21 \\
\hline 12 & J01MA12 & Levofloxacin & Floroquinolone & 0,5 & $\mathrm{P}$ & & 0,00 & 0,00 & 0,00 & 0,00 & 0,00 & 3,45 & 3,45 \\
\hline 13 & J01MA12 & Levofloxacin & Floroquinolone & 0,5 & $\mathrm{O}$ & & 0,00 & 2,51 & 0,73 & 0,00 & 0,00 & 0,00 & 3,24 \\
\hline 14 & J01XD01 & Metronidazole & Imidazole & 1,5 & $\mathrm{P}$ & & 0,00 & 0,00 & 1,26 & 0,00 & 0,00 & 1,88 & 3,14 \\
\hline & & & Total & & & & 7,06 & 9,46 & 12,98 & 11,50 & 7,54 & 18,00 & 66,44 \\
\hline
\end{tabular}


Tabel 3 Profil DU 90\% Penggunaan Antibiotik

\begin{tabular}{|c|c|c|c|c|c|c|c|}
\hline No. & Kode ATC & Jenis Antibiotik & Rute & $\begin{array}{c}\text { DDD/100 } \\
\text { Patient-days }\end{array}$ & $\begin{array}{l}\text { DU } \\
(\%)\end{array}$ & $\begin{array}{c}\text { DU } \\
\text { Kumulatif }\end{array}$ & Segmen DU \\
\hline 1 & J01DD12 & Cefoperazone & $P$ & 20,72 & 31,19 & 31,19 & \multirow{6}{*}{$90 \%$} \\
\hline 2 & J01DD04 & Ceftriaxone & $P$ & 20,18 & 30,37 & 61,56 & \\
\hline 3 & J01DD01 & Cefotaxime & $P$ & 8,27 & 12,45 & 74,01 & \\
\hline 4 & J01MA12 & Levofloxacin & $\mathrm{P}$ & 3,45 & 5,19 & 79,20 & \\
\hline 5 & J01MA12 & Levofloxacin & $\mathrm{O}$ & 3,24 & 4,88 & 84,08 & \\
\hline 6 & J01XD01 & Metronidazole & $\mathrm{P}$ & 3,14 & 4,73 & 88,81 & \\
\hline 7 & J01DC02 & Cefuroxime & $P$ & 2,83 & 4,26 & 93,07 & \multirow{8}{*}{$10 \%$} \\
\hline 8 & J01DD02 & Ceftazidime & $\mathrm{P}$ & 1,36 & 2,05 & 95,12 & \\
\hline 9 & J01FA10 & Azithromycin & $\mathrm{O}$ & 1,05 & 1,58 & 96,70 & \\
\hline 10 & J01DH02 & Meropenem & $\mathrm{P}$ & 0,84 & 1,26 & 97,96 & \\
\hline 11 & J01MA02 & Ciprofloxacin & $\mathrm{P}$ & 0,84 & 1,26 & 99,22 & \\
\hline 12 & J01MA02 & Ciprofloxacin & $\mathrm{O}$ & 0,21 & 0,32 & 99,54 & \\
\hline 13 & J01CA04 & Amoxicillin & $\mathrm{O}$ & 0,21 & 0,32 & 99,86 & \\
\hline 14 & J01DB05 & Cefadroxil & $\mathrm{O}$ & 0,10 & 0,15 & 100 & \\
\hline
\end{tabular}

(86\%). Pada pola kuman pada spesimen pus dengan jenis bakteri gram negatif, diketahui bahwa antibiotik dengan presentase effective clinically paling tinggi yaitu Amikacin (91\%), sedangkan antibiotik dengan presentase not effective clinically tertinggi yaitu Ampicilin (91\%), dan Nitrofurantoin (91\%).

Berdasarkan Gambar 2 pada pola kuman pada spesimen sputum dengan jenis bakteri gram positif tahun 2018, diketahui bahwa hampir semua antibiotik yang diujikan 100\% sensitif terhadap bakteri yaitu Staphylococcus warneri. Antibiotik yang menunjukkan sifat not effective clinically terhadap bakteri tersebut adalah Amoxicillin (100\%). Pada spesimen sputum dengan jenis bakteri gram negatif, diketahui bahwa antibiotik dengan presentase effective clinically tertinggi yaitu Amikacin (100\%), sedangkan antibiotik dengan presentase not effective clinically tertinggi adalah Ampicillin (100\%).

Berdasarkan Gambar 3 pada pola kuman pada spesimen darah dengan jenis bakteri gram positif tahun 2018, dapat diketahui bahwa antibiotik dengan presentase effective clinically tertinggi yaitu Amikacin (100\%), sedangkan antibiotik dengan presentase not effective clinically tertinggi yaitu Cefadroxil (100\%). Pada spesimen darah dengan jenis bakteri gram negatif tahun 2018, diketahui bahwa antibiotik dengan presentase effective clinically terbesar adalah Meropenem (80\%), sedangkan antibiotik dengan presentase not effective clinically tertinggi adalah antibiotik Gentamycin (100\%) dan Cefazoline (100\%).

\section{Pembahasan}

Evaluasi penggunaan antibiotik secara kuantitatif telah direkomendasikan oleh WHO dengan cara melakukan perhitungan DDD/100 patient-days. Nilai total DDD/100 patientdays yang semakin besar menunjukkan tingginya tingkat pemakaian antibiotik dalam 100 hari rawat. ${ }^{10}$ Perhitungan DDD/100 patient-days pada penelitian ini menghasilkan total nilai 66,44 . Hal ini berarti dalam 100 hari, setiap pasien rata-rata mendapatkan 66,44 DDD antibiotik setiap harinya. Hasil tersebut lebih rendah apabila dibandingkan 

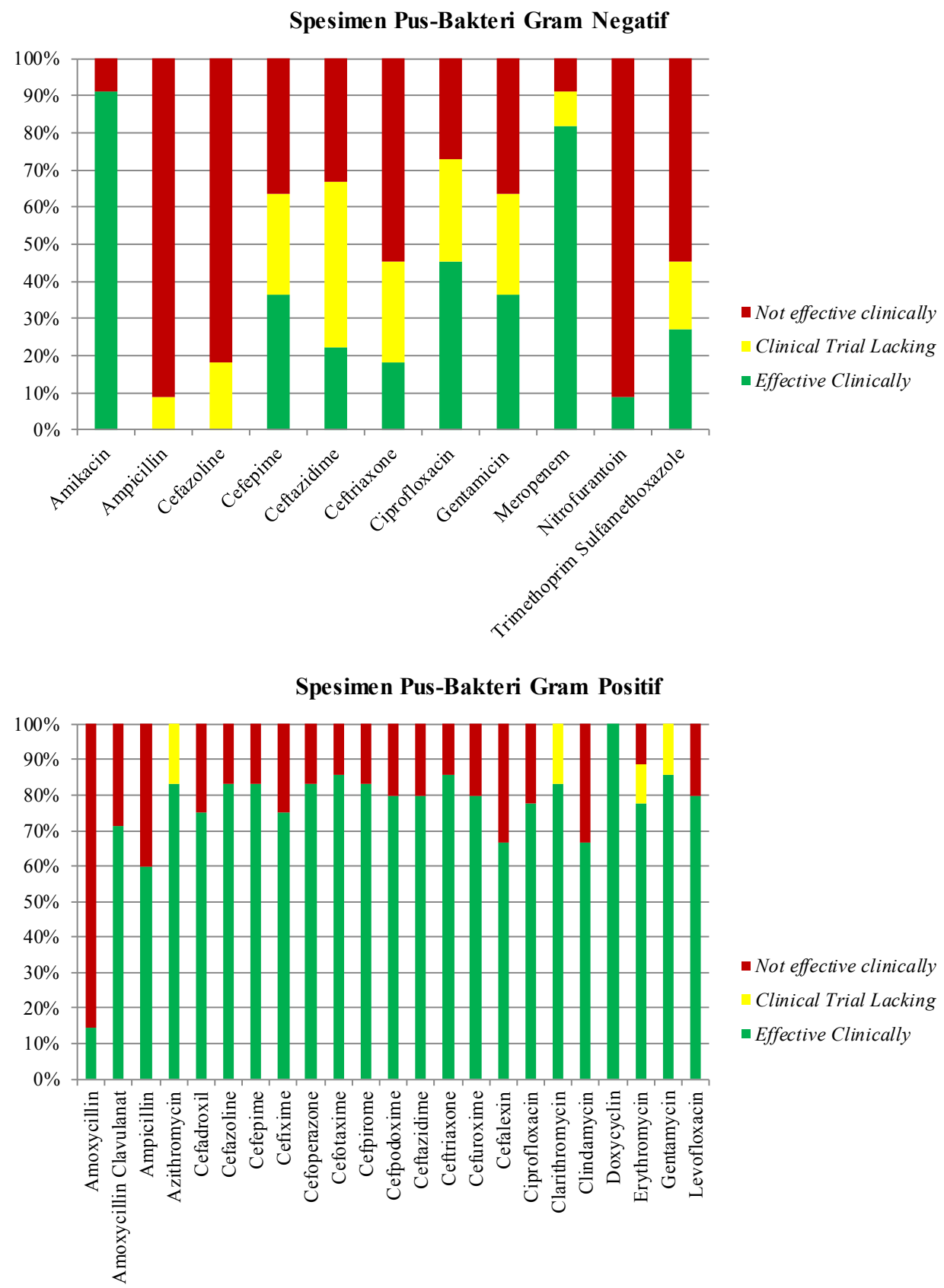

\section{Gambar 1 Diagram Spesimen Pus-Jenis Bakteri Gram Positif dan Negatif}

dengan dengan total $\mathrm{DDD} / 100$ hari rawat inap Bangsal Penyakit Dalam RSUD Bangil selama periode Juli-Desember 2016 yakni sebesar 399,97. ${ }^{11}$ Namun hasil tersebut lebih tinggi dibandingkan total DDD/100 patientdays Bangsal Penyakit Dalam RSUD Prof. Dr. Margono Soekarjo Purwokerto pada bulan Oktober-Desember 2017, yakni 60,49. ${ }^{12}$
Penggunaan suatu macam/kelompok obat dapat dikatakan berlebihan atau kurang dengan cara membandingkan tingkat konsumsi obat di suatu unit pelayanan kesehatan dengan yang lainnya. Hasil penelitian ini tidak dapat membandingkan selektivitas tingkat konsumsi antibiotik dengan rumah sakit lain karena terdapat perbedaan periode (lama 


\section{Spesimen Sputum-Bakteri Gram Negatif}

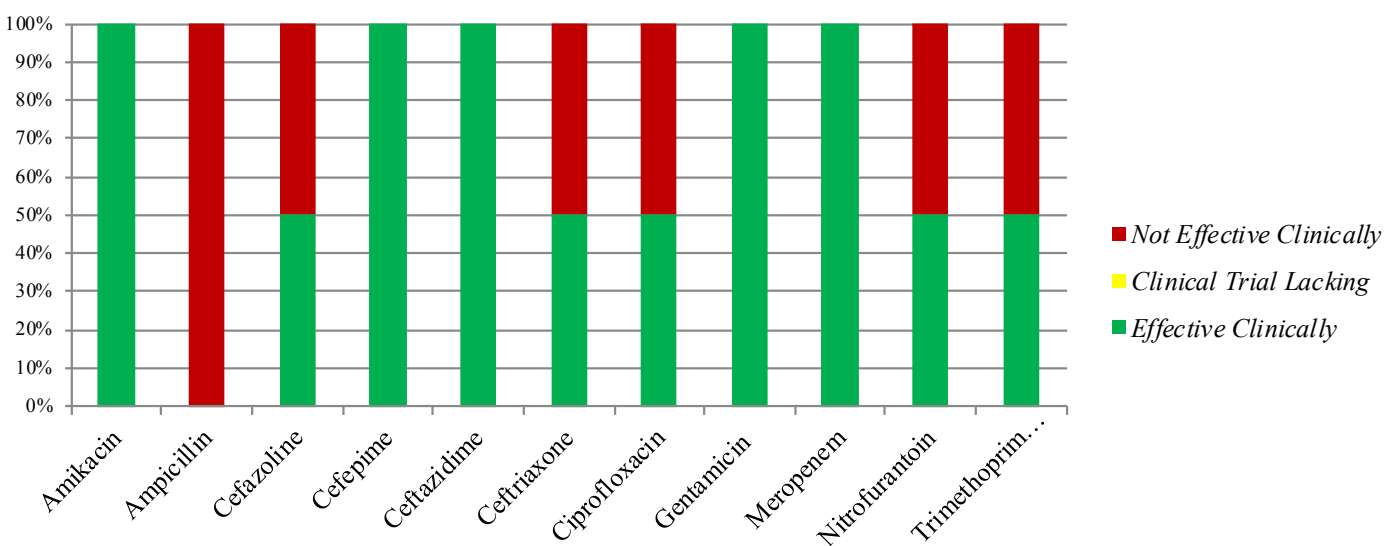

Spesimen Sputum-Bakteri Gram Positif

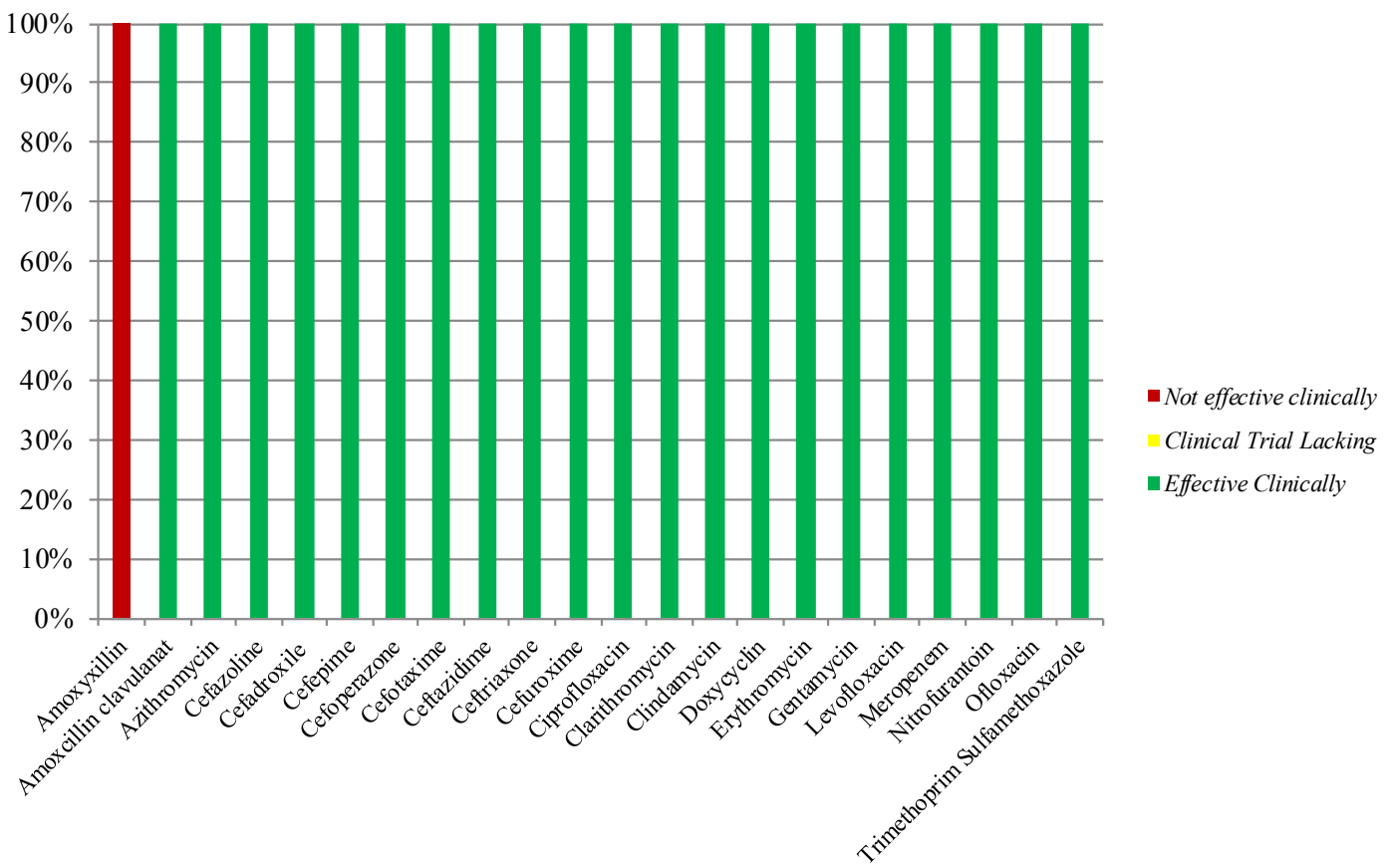

\section{Gambar 2 Diagram Spesimen Sputum-Jenis Bakteri Gram Positif dan Negatif}

penelitian), dan metode yang digunakan pada penelitian sebelumnya.

Metode DU 90\% digunakan untuk mempresentasikan penggunaan antibiotik dari yang paling banyak sampai yang paling sedikit. Antibiotik yang paling banyak digunakan dikelompokkan ke dalam segmen 90\%, sedangkan antibiotik yang sedikit digunakan dikelompokkan ke dalam segmen $10 \%$.
Berdasarkan hasil penelitian ini, data yang diperoleh dapat digunakan sebagai informasi dalam perencanaan pengadaan obat yang akan digunakan. Hasil penelitian ini menunjukkan bahwa antibiotik yang masuk dalam segmen 90\% terdiri dari Cefoperazone (parenteral) $31,19 \%$, Ceftriaxone (parenteral) 30,37\%, Cefotaxime (parenteral) 12,45\%, Levofloxacin (parenteral) 5,19\%, Levofloxacin (oral) 4,88\%, 


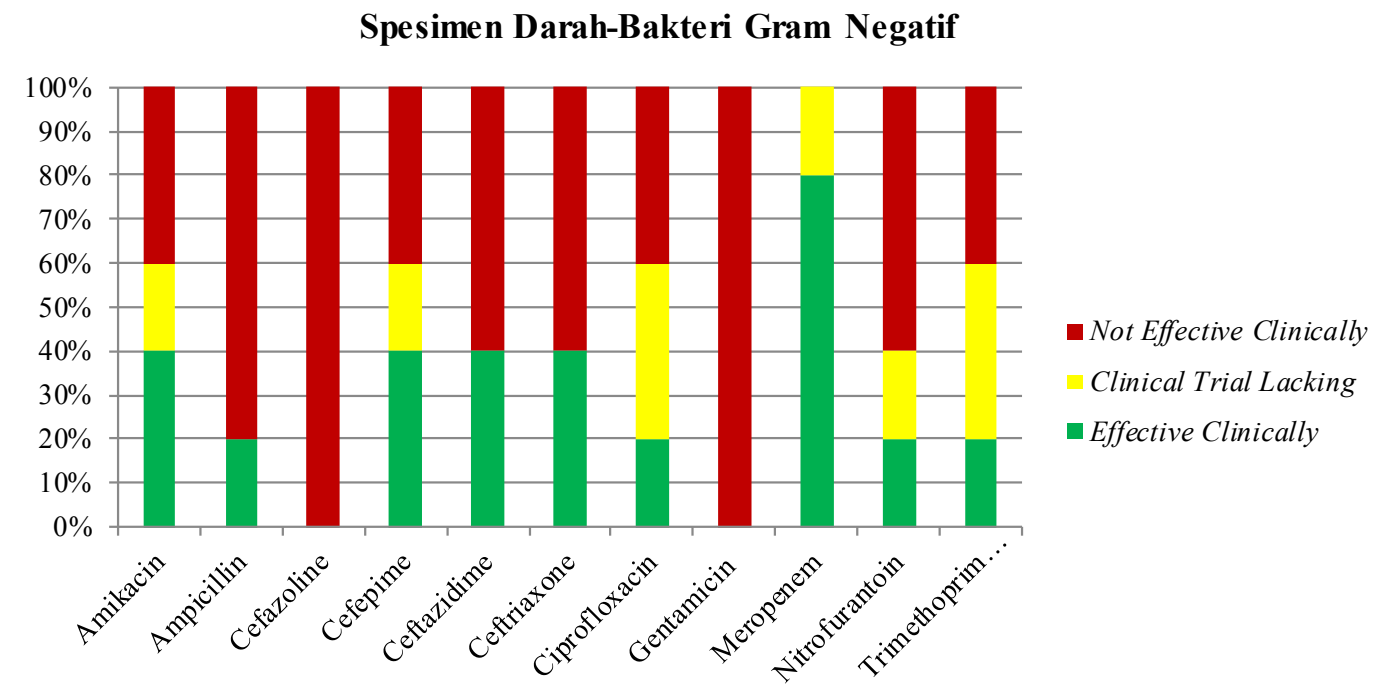

Spesimen Darah-Bakteri Gram Positif

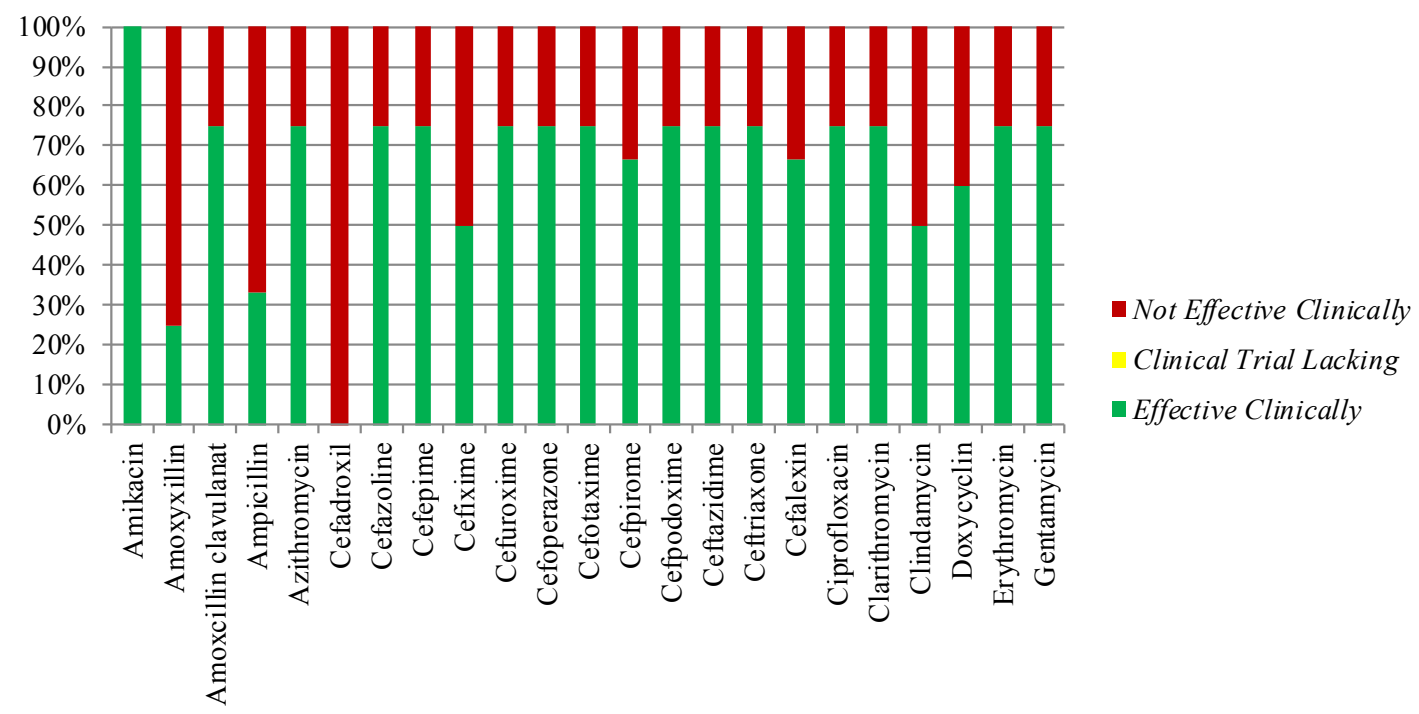

Gambar 3 Diagram Spesimen Darah-Jenis Bakteri Gram Positif dan Negatif

dan Metronidazole (parenteral) 4,73\%. Di lain pihak, antibiotik yang masuk dalam segmen $10 \%$ antara lain Metronidazole (parenteral) $1,88 \%$, Ceftazidime (parenteral) 1,36\%, Azithromycin (oral) 1,05\%, Meropenem (parenteral) 0,84\%, Ciprofloxacin (parenteral) 0,84\%, Ciprofloxacin (oral) 0,21\%, Amoxicillin (oral) $0,21 \%$ dan Cefadroxil (oral) $0,10 \%$. Dasar pemilihan antibiotik harus sesuai dengan efikasi klinik, sensitivitas, kondisi klinis pasien, mengutamakan antibiotik lini pertama/spektrum sempit, ketersediaan formularium rumah sakit, sesuai diagnosis, terapi, dan memilih antibiotik yang paling kecil untuk meminimalkan risiko terjadinya infeksi.

\section{Simpulan}

Kuantitas penggunaan antibiotik DDD/100 patient days di Ruang Perawatan Airlangga RSUD Kanjuruhan Kabupaten Malang pada periode Juli-Desember 2018 yaitu jumlah penggunaan DDD/100 patient days 
tertinggi adalah Cefoperazone (20,72), dan Ceftriaxone $(20,18)$. Total DDD/100 patient days sebesar 66,44 DDD/100 patient days. Antibiotik yang masuk dalam segmen $90 \%$ antara lain Cefoperazone (parenteral) sebesar $31,19 \%$, Ceftriaxone (parenteral) 30,37\%, Cefotaxime (parenteral) 12,45\%, Levofloxacin (parenteral) 5,19\%, Levofloxacin (oral) 4,88\%, dan Metronidazole (parenteral) 4,73\%. Isolat bakteri yang diperoleh sebanyak 120 isolat, dengan distrubusi bakteri gram positif $(49,17 \%)$ dan bakteri gram negatif $(50,83 \%)$. Isolat bakteri gram positif terbanyak adalah Staphylococcus aereus (30\%) dan bakteri gram negatif terbanyak adalah Escherichia coli $(15 \%)$ dengan sensitivitas antibiotik terbaik untuk bakteri gram positif adalah Clarithomicyn $(81,8 \%)$ dan untuk bakteri negatif adalah Amikacin (77,8\%).

\section{Ucapan Terima Kasih}

Penulis mengucapkan terima kasih kepada RSUD Kanjuruhan yang telah mengizinkan dan memberikan fasilitas untuk penelitian mengenai evaluasi kuantitatif penggunaan antibiotik. Penulis juga mengucapkan terima kasih kepada Lembaga Penelitian dan Pengabdian Masyarakat (LP2M) Universitas Islam Negeri Maulana Malik Ibrahim Malang.

\section{Pendanaan}

Penelitian ini didanai oleh Lembaga Penelitian dan Pengabdian Masyarakat (LP2M) Universitas Islam Negeri Maulana Malik Ibrahim Malang dengan nomor DIPA BLUDIPA 025.04.2.423812/2019.

\section{Konflik Kepentingan}

Seluruh penulis menyatakan tidak terdapat potensi konflik kepentingan dengan penelitian, kepenulisan (authorship), dan atau publikasi artikel ini.

\section{Daftar Pustaka}

1. World Health Organization. Commission on ending childhood obesity. Geneva: World Health Organization, Department of Noncommunicable Disease Surveillance; 2015.

2. Centers for Diseases Control and Prevention (US). Antibiotic resistance threats in the United States 2013. United States: Centers for Diseases Control and Prevention, US Department of Health and Human Services; 2013.

3. Utami ER. Antibiotika, resistensi, dan rasionalitas terapi. El-Hayah. 2011;1(4): 191-8. doi: 10.18860/elha.v1i4.1783

4. Febrina M, Sumiwi SA, Hartini S. Studi penggunaan antibiotik berdasarkan ATC/ DDD dan DU 90\% di bagian bedah digestif di salah satu rumah sakit di Bandung. Indones J Clin Pharm. 2016;5(4):293-8. doi: 10.15416/ijcp.2016.5.4.293

5. Pradipta IS, Febrina E, Ridwan $\mathrm{MH}$, Ratnawati R. Identifikasi pola penggunaan antibiotik sebagai upaya pengendalian resistensi antibiotik. Indones J Clin Pharm. 2012;1(1):16-24.

6. Brady M, Cunney R, Murchan S, Oza A, Burns K. Klebsiella pneumoniae bloodstream infection, antimicrobial resistance and consumption trends in Ireland: 2008 to 2013. Eur J Clin Microbiol Infect Dis. 2016;35(11):1777-85. doi: 10. 1007/s10096-016-2727-4.

7. World Health Organization. Guidelines for ATC classification and DDD assignment. Geneva: World Health Organization; 2013.

8. Rhodes A, Evans LE, Alhazzani W, Levy MM, Antonelli M, Ferrer R, et al. Surviving sepsis campaign: International guidelines for management of sepsis and septic shock. Crit Care Med. 2016; 45(3):486-552. doi: 10.1097/CCM.00000 00000002255

9. Kementerian Kesehatan Republik 
Indonesia. Peraturan Menteri Kesehatan Republik Indonesia Nomor 8 Tahun 2015 Tentang Program Pengendalian Resistensi Antimikroba di Rumah Sakit; 2015.

10. Sari A, Safitri I. Studi penggunaan antibiotika pasien pneumonia anak di RS PKU Muhammadiyah Yogyakarta dengan metode defined daily dose (DDD). J Ilmiah Ibnu Sina. 2016;1(2):151-62.

11. Rachmawati S, Fazeri RL, Norcahyanti I. Gambaran penggunaan antibiotik di
Bangsal Penyakit Dalam RSUD Bangil Kabupaten Pasuruan. J Pharm Sci Clin Res. 2020;5(1):12-21. doi: 10.20961/jpsc r.v5i1.35254

12. Lestari PD, Utami ED, Suryoputri MW. Evaluasi penggunaan antibiotik di bangsal penyakit dalam RSUD Prof. Dr. Margono Soekarjo Purwokerto periode Oktober-Desember 2017. Acta Pharmaciae Indonesia. 2018;6(1):20-8. doi: 10.2088 4/1.api.2018.6.1.1444

(C) 2021 Anggraini et al. The full terms of this license incorporate the Creative Common Attribution-Non Commercial License (https://creative commons.org/licenses/by-nc/4.0/). By accessing the work you hereby accept the terms. Non-commercial use of the work are permitted without any further permission, provided the work is properly attributed. 